\title{
The Imperative of Credible Elections for Sustainable National Development in Nigeria-Lessons from the Ekiti State Gubernatorial Election, 2014
}

\author{
Larry E. Udu ${ }^{1}$, Joseph Okwesili Nkwede ${ }^{1} \&$ Ezekwe Emmanuel A. ${ }^{2}$ \\ ${ }^{1}$ Department of Public Administration, Ebonyi State University, Abakaliki, Nigeria \\ ${ }^{2}$ Political Science Department, Ebonyi State University, Abakaliki, Nigeria \\ Correspondence: Larry E. Udu, Department of public Administration, Ebonyi State University, Abakaliki, \\ Nigeria. Tel: 234-80-3744-1746. E-mail: lamaken.larryudu503@gmail.com
}

\author{
Received: September 29, 2014 Accepted: October 13, 2014 Online Published: March 30, 2015 \\ doi:10.5539/jsd.v8n2p209 \\ URL: http://dx.doi.org/10.5539/jsd.v8n2p209
}

\begin{abstract}
Elections in Nigeria have been associated with irregularities and violence since $4^{\text {th }}$ Republic. The study examined the imperative of credible elections for sustainable national development in Nigeria with particular emphasis on Ekiti State gubernatorial election, 2014. Content Analytical Approach was adopted and the extract of the results of June, 21, 2014 election from 16 local governments in Ekiti State, Nigeria was critically analyzed. Guided by the humanistic theory, the study revealed that out of 3 political parties that contested at the polls, PDP won the 16 local government areas in the state and, the outcome was accepted by both the winner and losers of the contest. The study therefore, recommends that political office holders as chief servants of the people should improve the infrastructural needs and human capital development of their states and that the INEC ought to be truly independent of the executive to enhance the credibility of the electoral process in Nigeria. The paper concludes the politicians as a matter of urgency may draw lessons from Ekiti State poll and take proactive step to avoid individualism, lack of political will, sycophancy, and imbibe the culture of respecting the will of the populace as sovereignty belongs to the people and the will of the people can only be expressed in periodic and genuine elections.
\end{abstract}

Keywords: credible elections, sustainable national development, Ekitistate, INEC, Nigeria

\section{Introduction}

Election, which could be described as a widely and universally accepted means through which, by voting, individuals are openly and methodically chosen to represent a body or community in a larger entity or government, is one of the cardinal features of a democratic process. Truly, if the elementary definition of democracy is accepted as the government of the people, by the people and for the people, then elections would seem to be the only mechanism through which a democratic government can be realized and entrenched.

Previous and current efforts by Nigeria to institute liberal democracy as a system of government have always been either scuttled or severely constrained by the problems arising from elections. The issue has not been whether or when to hold elections, since that fact and necessity of elections are taken for granted in the practice of liberal democracy. Rather, the issue has been how to ensure and guarantee credibility and acceptability of elections and their outcomes (Kayode, 2005); cited in Onu and Momoh (2005).

With election so critical in a democratic political system, it is understable why one should be concerned with its fairness and freeness. As argued by the Nigerian social scientist (2003:1), without elections being held regularly and seen to be conducted in a transparently free and fair manner, democracy remains a sham, a forlorn hope, indeed and empty shadow of itself. It is precisely because of this fact, that virtually every analyst who comments on democratic elections, particularly in Nigeria, always stresses the issue of freeness and fairness; hence, credibility (see, among others Ujo, 2003 (a \& b); Olaleye, 2003; Bello, 2003, Sha, 2003; Nzongola-Ntaloja, 2001 Odeg, 2003 and, Diamond, 2002). It is common knowledge that elections, particularly in Nigeria, are often characterized by all manners of malpractices with their attendant, socio-political, economic and security challenges facing Nigeria as a nation. 
Against this backdrop, this paper aims at examining the imperative of credible elections for sustainable national development in Nigeria with particular attention to the Ekiti State gubernatorial elections, 2014. The paper attempts to provide answers to the following and related questions.

1) What factors constituted credible elections?

2) To what extent has the electoral body in Nigeria been responsible for credibility or otherwise, of elections in Nigeria?

3) What lessons can be drawn from the Ekiti, 2014 Gubernatorial Election?

4) What should be done to ensure credible election vis-à-vis sustainable national development in Nigeria?

The paper is divided into six sections. Section one deals with the introduction, bringing objectives of the study and theoretical framework to bear. Section two, presents the concepts of credible election, historical perspectives of the electoral institution in Nigeria and the electoral process; while section three, captures the methodology employed in the study. Similarly, section four focuses on the analysis and discussion of findings and section five and six wrapped up the paper with conclusion and recommendations.

\subsection{Objectives of the Study}

The specific objectives of this paper are:

1) To identify factors that constitute credible election;

2) To assess the contributions of the Independent National Electoral Commission (INEC) in ensuring credible elections in Nigeria and,

3) To examine the Ekiti 2014 Gubernatorial elections with a view to establishing possible lessons therefrom.

\subsection{Theoretical Construct of the Study}

The study adopted Maslow (1968), Human Hierarchic Theory of Needs. In this theory Maslow emphasizes on each person's innate need for self-actualization - the full development of potentialities. He opined that self actualization needs can be expressed or satisfied only after "lower" needs, such as safety, love, food, and shelter, have been met. For example, a child who is hungry most of the day will not attend to reading or drawing in school until properly fed. When reasonable safety and survival needs are assured, the next most pressing need is to belong. Similarly, the elite/godfathers who need political power by all means with the tendencies to secure the power because they have satisfied the lower order needs require self-actualization to sustain their existence against the common. Human beings need to love and to feel loved, to be in physical contact with one another, to associate with others, and to participate in groups or organization (Shaffer, 1978).

To Maslow, the development of a state is entirely dependent on the level of development of the people that make up such a state. Nigerian nation has not developed because the significant aspect of human capital has not developed, the tendencies that other parts can develop is in doubt. The situation as it may have paved way for the godfathers, irresponsible office holders; weak government institutions use all illegal methods to impose their political sons and daughters on the people. The theory provides a holistic theory of personality and has close ties to existential philosophy. It seeks to maximize human potential, to rescue the will from drives and instincts as well as from environmental programming. It maintains that people can make choices about their own lives. They can, if they wish, be spontaneous, self-determining, and creative. Humans are assumed to set apart from other animals by their superior ability to use symbols and think abstract terms. However, if human capital development can be adequately addressed, it will make all Nigerians to value the sanctity of human life; make honesty a national character and wage an inner and moral war against corruption and election rigging in Nigeria and deep rooted sustainable national development will be ensued.

Hamanistic psychologists emphasize consciousness, as much as unconsciousness, as a basic human process. To them people experience themselves, as well as others, as spontaneously self-determining and creatively striving toward goals (Severin, 1974).

\section{Literature}

\subsection{The Concept of Credible Election}

Elections are said to be credible, when rules, regulations and laws governing the electoral process are followed and ultimately, credible candidate are freely and fairly selected to represent the electorate. In other words, a free and fair election, legitimizes an electoral outcome. According to Diamond (2002) cited in Kayode (2005), there are four major variables on which the concept of free and fair elections rests. These are: (i) the political parties; 
(ii) the individuals; (iii) the voting process, and (iv) the election outcome. Starting with the political parties, he argued that in a multiparty democracy, for an election to be considered as free and fair, the:

Parties must be free to compete, to organize, to recruit members, to articulate policies, to stage relies and to solicit votes. The less the political system restrains opposing parties from the business of organizing and campaigning, and the less it systematically, favours a particular party (typically the ruling party), the freer and fairer the election may be said to have been.

By the same logic, for an election to be free and fair, the:

Individual must be free to participate in the political process - to join the party of their choice, to campaign for it, to seek political office in its platform and of course, to vote for it (or not to vote at all).

Furthermore, on the voting process:

Each person should have one and only one vote, and... each person should be counted equally... no one who satisfies some limited set of conditions (such as minimum age and sound mind) should be refused registration, no registered voter should be prevented from voting, nor should anyone be allowed to vote more than once, nor should any votes be counted for a party except those individuals legally cast, nor should any legally and properly cast votes be discarded or disregarded.

And, on the election outcome, an election would be free and fair if the results are

Accurately reported and the legitimate voters allowed to assume office.

Accordingly, when all the conditions germane to the four variables as defined above are observed in the process, conduct and outcome of an election, that election could be considered to be free and fair; hence, credible. However, the taste of the providing is often believed to be in the eating. It is common knowledge that the above outlined conditions are hardly possible in any election particularly in Nigeria. The activities of such bodies or group like the Electoral Commission, the behaviour of politicians and security agents, often determine how far, such conditions as highlighted can be possible. It is therefore, pertinent at this juncture, to examine the historicity of the Independent National Electoral Commission of Nigeria, the INEC, with a view to determining the extent to which it has contributed to credible election or otherwise, in Nigeria.

\subsection{The INEC - A Historical Perspective}

The advent of Clifford Constitution (1922) introduced the elective principle for Lagos and Calabar as the basis for political representation in the colonial political structure (Seteolu, 2005) cited in Leweanya, (2005). Several reviews of the electoral process in Nigeria under the 1946, 1951 and 1954 constitutions further expanded the political horizon and encouraged political participation. Evidently, the 1959 elections set the stage in the context of enthno-regional parties.

The problems of the electoral authorities in Nigeria started with the post-independence Federal Electoral Commission (FEC) which had Sir, Kofo Abayomi as its first head and which was later replaced by Mr. EyoEsua (Aderemi, 2005). However, the tenure of that Commission was abrogated by the 1966 military coup. About ten (10) years later, and that was in 1976, General Obasanjo established the Federal Electoral Commission (FEDECO) headed by Chief Michael Ani and subsequently, promulgated Decree 41 of 1979 (Jinadu, 1981). Unfortunately, the contentious issue of two-third of nineteen state forced Chief Ani out of FEDECO and he was immediately replaced by Justice Ovie-Whisky. Furthermore, the allegiance of FEDECO to the Federal Government and the fraud of the 1983 elections caused its replacement by National Electoral Commission (NEC) by Decree 23 of 1987 and Professor Eme Awa was appointed as its head. Consequently, upon the attempted ban on erstwhile politicians and the local government elections of 1987 which was conducted on a zero party basis, professor Awa was removed and immediately replaced with Professor Humphrey Nwosu. The Nwosu led NEC registered 13 political parties in 1990 but the Babangida's administration cancelled it and imposed two parties: the National Republican Party (NRC) and the Social Democratic Party (SDP) on Nigerians.

The INEC under Prof. Nwosu conducted the June 12 election, released results in 14 out of 30 States but was abruptly stopped by the military, dashing the hope of Chief MKO Abiola of the SPD who was poised to emerge as president of the country. Nwosu was replaced with Prof. OkonUya whose tenure witnessed widespread condemnation by Nigerians on the ground that president Babangida appropriated Abiola's mandate. Babangida handed over to Chief Ernest Shoneken's interim government which was sacked by General Sani Abacha in 1993; who dissolved NEC, replaced it with the National Electoral Commission of Nigeria (NECON) under Chief Dagogo-Jack. He was equally under the military government manipulations until the sudden death of General 
Abacha in 1998 when Abdulsalami Abubakir dissolved all his political structures and reconstituted the Independent National Electoral Commission (INEC) with Justice Ephraim Akpata as its head. Justice Akpata lived up to expectation but was succeeded by Dr. Abel Guobedia when he died in 2000. Guobedia was again manipulated by the SDP government in the 2003 general elections which was adjudged as one of the worst elections the country has ever had since the birth of democracy in Nigeria. The contagious story was continued in 2007 election under Professor Maurice Iwu who was replaced with the incumbent Professor AtahiruJega. It is clear from the foregoing, that there have been fundamental structural and institutional constraints which subject electoral management bodies to government manipulations and subsequently marred the history of electoral administration in Nigeria.

\subsection{Electoral Process in Nigeria}

Electoral process in Nigeria is often conceived to be equivalent to election or electoral system. The concept of electoral process however, reaches beyond the method of choosing public office holders; or the method of translating votes into seats or decision as to who has won an election. Essentially, the most useful way to comprehend the electoral process is to explore a descriptive conceptualization, which exposes the distinctive features of the process.

According to Nwabueze (1993) cited in Onu \& Momoh (2005), the electoral process embraces within its ambit, all the institutional procedures, arrangements and actions involved in elections. Thus, the electoral process includes election observation and verification activities carried out by local or international bodies or both (Onu \& Momoh, 2005). It also includes establishment of institutions and structures that will mobilize the populace towards involvement in the electoral process, and provides the rule and regulations that govern the process. The electoral process essentially, is all-encompassing process involving any issues and operations which are also elastic, depending on the type of political system and the level of maturity of the democratic process.

The electoral process can be divided into the constitutional and non-constitutional aspects. The constitutional aspect has issues prescribed in the constitution such as the body responsible for the electoral process and the independence of such a body (INEC), while the non-constitutional aspect such as voters' register, procedure at election, electoral offences, etc, are issues, more appropriately covered by acts of the National Assembly. Electoral process should therefore be understood as a defining and regulatory process in the democratic contest.

In Nigeria, unlike in the advanced democracies of the world, the electoral process has often been undermined by political contest, fraud and malpractice of varying degree and intensity - a situation that has made national development suffer a severe setback (Udu, 2013).

\section{Methodology}

Content analytical approach was adopted for the paper. Data were collected using information from official document, direct observation, media commentaries and from scholarly writings on elections and democratic consolidation in Nigeria.

\section{Analysis and Results}

\subsection{Overview of Elections in Nigeria - Framework for Analysis}

Viewed against the standard of definition of free and fair elections (credible election) in Nigeria's various general elections from 1959 uptill 2003 and even the most recent ones had always fallen short of expectation in various aspects.

On the aspect of political parties, many of them have almost always been allowed to operate as witnessed in the first, second and fourth republics. However the only exception to this, was the abortive third Republic (1999-1993) when the military government overseeing the "democratic" transition to civil rule, at that time, outlawed the different political parties and decreed only two parties into being. These parties had also been free to compete, organize and recruit their members, to articulate their policies, stage political rallies and campaigns, etc. Be that as it may, the ruling party in elections organized under civilian governments constituted by one of the competing parties had always enjoyed certain advantage over and above their rivals. For instance, the ruling political party, in addition to being in control of the state resources and the coercive apparatus, such as the police, Armed Forces, and the State Security Service, also has the constitutional power to appoint the national electoral body which served both as umpires at election and as electoral law maker. Only during military regimes in Nigeria (1997-1999) did these systemic advantages not hold sway.

Successive elections in Nigeria had always fared well on the aspect of freedom of individuals to participate in the political process with the exception of the extremely tele-guided military to democratic transition of the early 
1990s when certain politicians were repeatedly banned and unbanned at will, by the military government. Regarding the voting process, elections in Nigeria had always left much to be desired. Legally, each eligible adult had a single vote which counted equally with the vote of any other. Similarly, every individual who satisfied the minimum age requirement (18 years) and was of age and sound mind, was registered and could exercise his/her voting right. In reality, however, a combination of administrative inefficiency, deliberate political scheming by some of the stakeholders in the electoral process had always raised formidable obstacles that would expose the voting process to serious crisis of credibility. This situation is true of all elections in Nigeria, particularly, the 2003 general elections which Odey (2003) described as "this madness called election 2003. The voting process was characterized by all manners of fraud, manipulation, violence and irregularities that often resulted in victory being given to the wrong candidate or party. In the celebrated case of the June 12, 1993 presidential election, the counting of votes was scuttled and the apparent winner of the election was denied opportunity to assume office. As a result, election outcomes were always highly disputed and often rejected by declared losers. According to Ujo (2003) cited in Omojuwa (2005), the shortcomings of successive elections in Nigeria are attributable to many factors...:

i) The activities of the institutional structure responsible for conducting elections;

ii) A poor economic environment, which did not make it possible for democratic values to thrive;

iii) The lack of political integration, which made the electorate to interpret modern politics in primordial terms; and

iv) The universal law of organization, which made party leaders to adopt undemocratic means as a strategy for survival in power.

Of all these factors, the first one appears to us here to be the most critical, given that what transpires at the level of institutional administration of the election process determines to a very large extent, whether the process would eventually be free and fair. This position is corroborated by Sha (2003) and Diamond (2002).

Another associated challenge to credible elections in Nigeria is the syndrome of "Godfatherism" with its attendant sycophantic culture (Udu, 2013). These factors influence elections negatively and result to election malpractice of different forms and degrees. For instance, the Godfathers impose candidates against the popular choice of the masses during party primaries and in the actual elections in Nigeria. This situation is attributable to weak institution and high level of poverty, disregard of the constitutional requirements, disheartening abuses of citizens' rights and the rule of law which atimes, usher in the most dishonourable candidates to assume power often to the detriment of the masses. Consequently, public functionaries occupying exalted leadership positions in Nigeria have failed to apply appropriate leadership techniques in addressing the perennial challenges facing the country. Hence, rather than assisting the country with their acclaimed wealth of knowledge to develop, they have succeeded in aggravating the country's woes (Nwagboso \& Duke, 2012).

\subsection{Implications for Sustainable National Development}

Among the indices for measuring national development include but not restricted to: quality of democratic governance, institutional and human capacities which by extension include: literacy level, gross domestic product per capita, level of employment, poverty, life expectancy amongst others. These are low in Nigeria. According to Nkwede (2014), low life expectancy, manifest in the form of massive illiteracy, parity in purchasing power, low gross domestic product per capita, unemployment, hunger, disease, malnutrition, infant mortality, etc. The United Nations Development Programme (UNDP) report (1997) cited in Nkwede (2014), ranked Nigeria to occupy the position of 146 of 174 identified as poor countries. The above situation is quite unfortunate for a country richly blessed by nature as Nigeria. These are attributable to poor governance resulting from having the wrong people occupy exalted leadership positions through electoral fraud.

Similarly, the education system which is the hallmark of national development of any nation has also not received adequate attention by successive Nigerian governments. For instance, Nigeria as the $7^{\text {th }}$ most populous country on earth with $158,143,000$ people or $2.26 \%$ of the world population (UN Estimate \& Nigeria's office of National Statistics, 2010) has 124 universities (public and private) much fewer than Ethiopia, $14^{\text {th }}$ most populous country with a population of $83,321000(1.2 \%)$ with 141 Universities. Considering the population of youth seeking university admission, the above figure is grossly inadequate; moreso, when there are restrictions here and there on University admissions put in place by the National Universities Commission (NUC). As a result, admissions are done by quota which frustrates admission seekers. For instance, in the 2012 Unified Tertiary Matriculation Examination across the country, a total of 1,503,931 candidates registered to compete for 500,000 admission slots (Alechenu, 2012). In the 2010 and 2011 years, candidates registration was 1,375,642 
and1493,603 respectively (Dibu Ojenude, JAMB Registrar in a press briefing, Abuja March, 20, 2012). Similarly, the 2009 JAMB, 588,543 qualified for admission and only 200,000 $(20 \%)$ candidates were offered admissions (Fortune Education, April, 23, 2009). These situations have continued to worsen progressively over the years.

In addition to the lack of adequate space for tertiary education in Nigeria, the existing ones are not even adequately funded to operate optimally. This has given rise to incessant industrial strikes by the Academic Staff Union of Universities (ASUU), disruption of the academic calendar and ultimately, impacting negatively on students/graduates from Nigerian Universities. Many of the University graduates are either not employed or at best, unemployable. Considering the level of frustration of youths and the Nigerian masses vis-à-vis the level of affluence constantly displayed by the ruling class, it becomes obvious why there is high level of insecurity in the country.

\subsection{The Ekiti Gubernatorial Election, 2014}

At this juncture, it becomes pertinent to examine the gubernatorial election in Ekiti State, Nigeria conducted on June, 21, 2014. The result of that election is placed in table 1, below;

Table 1. Ekiti state 2014 governorship election result

\begin{tabular}{rlrrr}
\hline S/N & LGA & APC & LP & PDP \\
\hline 1 & ADO & 13,927 & 2,065 & 41,169 \\
2 & EFON & 3,422 & 358 & 5,335 \\
3 & EKITI EAST & 8,584 & 762 & 12,498 \\
4 & EKITI WEST & 7,860 & 884 & 10,702 \\
5 & EKITI SOUTH WEST & 6,746 & 1,413 & 11,038 \\
6 & EMURE & 4,332 & 1,527 & 7,086 \\
7 & GONYIN & 8,138 & 714 & 11,046 \\
8 & IDO/OSI & 7,134 & 1,182 & 13,045 \\
9 & IKERE & 7,989 & 585 & 16,197 \\
10 & IKOFE & 8,804 & 1,259 & 14,238 \\
11 & ILEJEMEJE & 3,336 & 165 & 3,670 \\
12 & IJERO & 9,348 & 1,554 & 13,814 \\
13 & IREPODUN/IFELODUN & 6,834 & 3,555 & 13,038 \\
14 & ISE/ORUN & 5,809 & 600 & 10,136 \\
15 & MOBA & 7,994 & 1,000 & 8,878 \\
16 & OYE & 10,176 & 512 & 11,200 \\
& TOTAL & $\mathbf{1 2 0 , 4 3 3}$ & $\mathbf{1 8 , 1 3 5}$ & $\mathbf{2 0 3 , 0 9 0}$ \\
\hline
\end{tabular}

Source: INEC, Ekiti Election Result, 2014.

One can observe from the above table that out of the total vote cast, the Peoples Democratic Party (PDP) emerged as the winner with 203,090 votes representing 59.44 percent. Evidently, the PDP won in all local government areas in the State against all other parties in the contest. The All Progressive Congress (APC) party took the second position in the election with (35.25\%), and the Labour Party (LP) took third from the result of the election $(5.31 \%)$ representing the total population of the electorate. The empirical examination revealed that election in Nigeria for sustainable national development can thrive only when poverty level of electorate is at its minimal level. Though financial inducement may not be completely ruled out from the Ekiti election, it is evident that the people clearly voted according to their choice and convictions. This is because; it is not easy to defeat an incumbent in his own state no matter the level of influence from the ruling party. It may be argued that the ruling PDP influenced the people's choice at the election but the fact that there were no protests from the electorate and the acceptance of the defeated incumbent governor, markedly disproves this view point. This view is even made much more convincing when one compares it with the inconclusive gubernatorial elections in Anambra State in 2013. Here, the then incumbent governor, Peter Obi of All Progressive Grand Alliance (APGA) 
defeated the PDP candidate, Chris Ngige, despite the pressures and financial muscles of the ruling PDP - a situation that proves that it is not altogether a matter of party that played out, but a factor of who was being voted for, his pedigree, and score- cards.

Secondly, many political commentators have argued that the Ekiti victory was a reaction to the breeding views that the APC is apparently associating itself with insurgency due to it's over politicization of the Boko-Haram insurgency in Nigeria. Thus the south, haven watched with trepidation, the experiences of the Northern Nigeria since the advent of Boko-Haram devilish activities, did not want to give any chance whatsoever, to infiltrations of such activities in the south; hence it's support of PDP candidate to emerge as the Ekiti governor. The landslide victory of the PDP in Ekiti tends to support this view point. Compared with the similar situation in Anambra State in 2013, one observes that, though the then incumbent APGA retained its position, in Anambra State after the elections, its victory was not landslide. For instance, table 2 shows that the PDP defeated APGA in Dunukofia and Oyi Local government areas with 4,907 and 9,123 votes, respectively; while the APC defeated both the APGA and the PDP in the Idemili and Nwewi North LGAs with 7,135 and 4,846 votes respectively. It is therefore, safe to conclude that the Ekiti people voted from their conviction and not on party basis; and this, is commendable. For the politicians, Ekiti State is a lesson in democracy in Nigeria and Africa at large, save the crisis and violence that dogged the campaigns by the two leading parties, the Ekiti election had all the ingredients of advanced democracies (Akam, 2014). The outgoing governor not only accepted the result of the election as the will of the people but restrained also his supporters from any form of demonstration as often observed in past elections in Nigeria. According to Akam (2014), the outgoing governor, the APC flag bearer, lambasted the undemocratic elements, within APC circle who had wanted him to reject the result. The undemocratic position of the APC is evident in her condemnation of congratulatory message to the governor-elect; describing that as 'un-Africa' or 'un-Nigeria' The outgoing governor had the political will to respect the wishes of his people and noted that Nigerian democracy is fragile and needed to be strengthened and deepened. Political losers most time, devote their energies on frustrating whatever effort their opponents try to make. They do this through court cases, or instigating their supporters to revolt against the government. The disheartening part is the experience where government public institutions had been set ablaze just to register dissatisfaction against winners of elections. All these were not observed in Ekiti State after the gubernatorial election under review.

Furthermore, the result of the study corroborates, Ovwasa (2013); Ochana, Ndem, Ogbaji,Ogbaji, \&Ogbole, (2014) and Ogbonnaya, Omoju, and Udefuna (2012), which amplified that situations such as financial inducement and related anti-social factors erode national development and good governance.

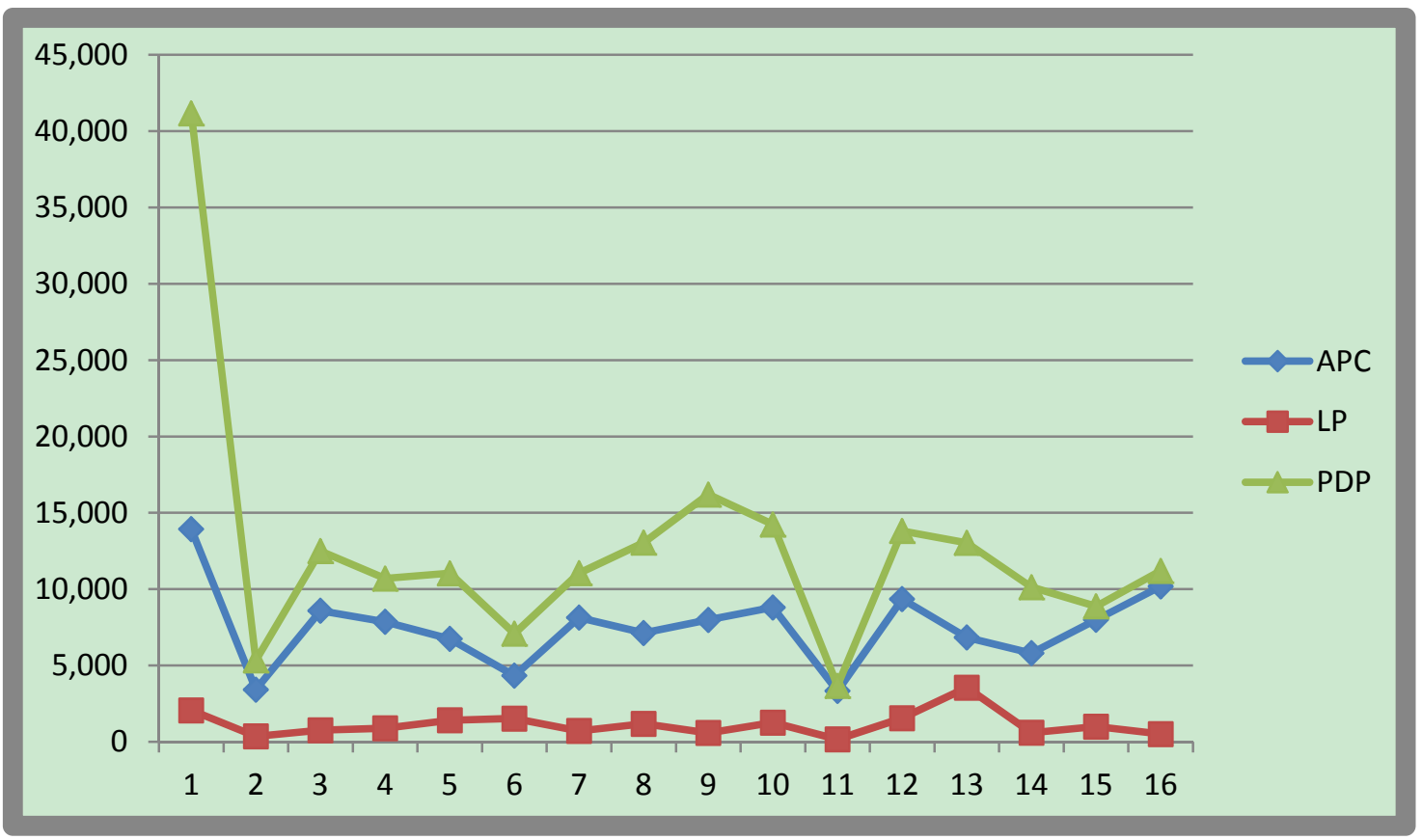

Figure 1. Graphical presentation of Ekitistate gubernatorial election result 2014

The graphical representation of the result of the election shows that Labour Party (LP) scored below 5,000, while 
APC made 15,000 and PDP scored above 40,000 to emerge the winner of the election. The PDP victory was attributable to experience in grassroots democracy unlike the incumbent governor of the APC who was said to have received protest votes as result of neglect of human capital development and related issues in the state.

The official result of the inconclusive Anambra Governorship Elections as announced by INEC in 2013, is presented in table 2 .

Table 2. Anambra governorship election held November, $16^{\text {th }} 2013$

\begin{tabular}{llllll}
\hline S/N & LGA & APGA & PDP & APC & LP \\
\hline 1 & AGUATA & 10,180 & 4,275 & 5,275 & 1,129 \\
2 & AYAMELUM & 9,121 & 5,681 & 1,827 & 624 \\
3 & ANAMBRA EAST & 15,300 & 5,579 & 1,418 & 511 \\
4 & ANAMBRA WEST & 5,128 & 3,966 & 2,478 & 321 \\
5 & ANAOCHA & 14,563 & 2,948 & 3,174 & 733 \\
6 & AWKA NORTH & 5,385 & 3,943 & 1712 & 474 \\
7 & AWKA SOUTH & 9,206 & 5,689 & 6,596 & 1,648 \\
8 & DUNUKOFIA & 3,670 & 4,907 & 3,522 & 1,236 \\
9 & EKWUSIGO & 6,815 & 4,426 & 2,958 & 1,692 \\
10 & IDEMILI NORTH & 2,795 & 1,462 & 7,135 & 643 \\
11 & IDEMILI SOUTH & 2,899 & 3,786 & 9,539 & 1,021 \\
12 & IHIALA & 10,067 & 5,517 & 4,069 & 1,854 \\
13 & NJIKOKA & 10,753 & 5,630 & 4,585 & 754 \\
14 & NNEWI NORTH & 3,076 & 1,942 & 4,846 & 18,014 \\
15 & NNEWI SOUTH & 8,145 & 3,031 & 2,676 & 2,214 \\
16 & OGBARU & 11,716 & 6,114 & 7,687 & 95 \\
17 & ONITSHA NORTH & 10,842 & 4,947 & 7,616 & 776 \\
18 & ONITSHA SOUTH & 9,786 & 3,520 & 7,094 & 716 \\
19 & ORUMBA NORTH & 9,161 & 4,567 & 3,343 & - \\
20 & ORUMBA SOUTH & 6,338 & 4,003 & 3,147 & 1,265 \\
21 & OYI & 6,994 & 9,123 & 3,373 & 206 \\
& Total & $\mathbf{1 7 1 , 9 4 0}$ & $\mathbf{9 5 , 0 5 6}$ & $\mathbf{9 4 , 0 7 0}$ & $\mathbf{3 5 , 9 2 6}$ \\
\hline Soun & INECAnam & & &
\end{tabular}

Source: INEC, Anambra State Governorship Election Result, 2013

\subsection{Lessons from the Ekiti Election}

When one talks of a lesson to be learnt from any particular event, certain ideas come to mind. Some of the ideas that may come to mind are (i) That the event is exemplary and may serve as a recipe; (ii) That the event constitutes some warning alert and has some far-reaching implications and (iii) That the event is simply informative. The above circumstances are evident in the Ekiti 2014 Elections.

In the first place, Chief Peter AyodeleFayose was elected as governor of Ekiti State for the second time. His first tenure was truncated by an impeachment in October 30, 2006 by the then State House of Assembly. Many viewed his impeachment as haven been masterminded by some political heavy weights both at the state and at the Federal levels. This view point is supported by the September 22, 2014, attack of the High Court Judge, Justice John Adeyeye during a proceeding on the eligibility of the governor to contest the election. This is a clear case of some hidden forces that did not want Fayose back as Ekiti governor. However, the fact that, despite the impeachment of 2006, Fayose was overwhelmly elected as governor in 2014 in what has been described as a free and fair election in Ekiti State, proves beyond doubts that Ekiti people loved him and that he must have performed creditably during his first tenure as governor of the state. The lesson here is that people have grown to 
insist on who they want to govern them and are prepared to fight and protect their votes in favour of their choice/will.

In the second place, it could be argued that Ekiti people know their governor much as he also understands precisely want the people needed most. This argument is supported by Fayose's "stomach infrastructure" campaign which he set up after his inauguration on October, 16, 2014 by appointing a Special Assistant on Special Duties and Stomach Infrastructure (Daily Independent, Tuesday October, 21, 2014). The idea behind stomach infrastructure, which is a new terminology in Nigerian Politics, is that food is essential for the hungry and that provision of food predominates all other considerations.

According to the governor, "you can put a tar on the road but if I don't have a car and I'm hungry, then that tar is meaningless. Tarring our road is wonderful but putting food inside the stomach is very important (Falobi, in Daily Independent, Oct., 21, 2014). One can deduce from the above that there is hunger and pervasive poverty in Nigeria. The lesson is that Nigerian government ought to urgently address the issue of grassroots poverty prevalent all over the country. Despite the plague of poverty and hunger, the idea of stomach infrastructure would have amounted to a great insult on the people's sensitivity. But it did not, because one has to be alive to talk of democratic dividends.

Evidently, the issue of poverty had existed since the evolution of the Nigerian nation. The Federal Office of Statistics Reports (1999) cited in Nkwede (2014), showed that between late 70s and early 1990s, the poverty level in Nigeria stood at 27 percent, but subsequently jumped to 46 percent as at 1996 when most countries within the poverty bracket were moving towards complete poverty eradication in their respective states (Osagie, 2007).

Apparently, successive military and civilian administrations in Nigeria had initiated poverty eradication programmes to address the issue of poverty in the country. For instance the General Obasanjo military regime's Operation Feed the Nation (OFN), the Green Revolution Programme of the ShehuShagari Civilian regime; the President Babangida's (1985-1993) Directorate for Food, Road, and Rural Infrastructure (DFRI) and the General Sani Abacha's Family Economic Advancement Programme (FEAP) amongst others. Yet, poverty has remained endemic in the country. According to Eminue, (2005) \& Igbuzor, (2006), factors such as gross mismanagement of the country's scarce resources by our corrupt and dishonest leaders; long military leadership in the country; abandonment of agriculture for oil economy and unstable economy are responsible for pervasive poverty and hunger in Nigeria.

Another lesson from the Ekiti election is the maturity and sportsmanship displayed by the governors involved. The outgoing governor, Kayode Fayemi, not only accepted the election result but restricted his supporters from any form of demonstration. This gesture, according to Akam (2014) was described as strange, 'un-African' or Un-Nigeria' and, it is commendable and ought to serve as a big lesson to Nigerian politicians who think that leadership is their birth right, and that they must either win at all cost or make the system ungovernable to their political opponents.

Evidently, considering the historicity of election in Nigeria, particularly, the 2003 and 2007 elections which to Carson (2011) were "deeply flawed", the Ekiti State gubernatorial election 2014, shall continue to be a lesson to Nigerian politicians and indeed the electorates.

\section{Conclusion}

The theory of needs, the nature of state and the behavior of the political elite guided our appraisal of the voter and elite behavior and their implications in the much desired credible elections in Nigeria. We observed the volatile nature of electoral contests as a result of the attractive nature of the state, godfatherism, money politics and the manipulation politics of the governing elite. These problems pose the challenge of reconstructing politics and re-legitimizing the political process. The envisaged tasks will involve the political class, electoral organ, security agencies and civil society with a view to evolving credible electoral process/elections, expanding the political space and consolidating democratic institutions and processes. However, the Ekiti gubernatorial election, 2014 is considerably a boost to grassroot democratic participation in Nigeria; and, it is commendable.

\section{Recommendations}

1) There is need for Nigerians irrespective of colour and race even gender to call to mind on the vision, values and aspirations of Nigerian's founding fathers, particularly on the areas of credible election, good governance, formulation and implementation of people oriented policies and programmes through good leadership. 
2) There is need to jettison godfatherism in Nigerian election if the nationmust live up to its national development. This will help to develop self-confidence in the voters and citizens and they will be able to successfully cope with and fight associated election fraud

3) It may be argued that money politics and vote-buying cannot be completely eradicated in Nigeria election. To a reasonable extent people can adopt mechanisms by which its negative consequences on good governance can be minimized. Strict adherence to spending limit during election campaign should be observed.

4) The Nigerian economy must be repositioned to empower the people economically. This is because where poverty is minimal the electorates can then make independent electoral decisions in voting for credible politicians' rather least qualified candidate that specialized on money spending.

5) The 1999 constitution should be amended to strengthening INEC's legal framework and the INEC as an electoral body ought to be truly independent of undue influences and manipulations by the government in power.

6) Similarly, in strengthening its legal framework, the INEC Chairman, Commissioners, Resident Electoral Commissioners and Secretary should be nominated through an independent process of voting instead ofby presidential appointments. In this way, merit and credibility will be given to the positions.

\section{References}

Aderemi, A. (2005). Electoral Commissions and Construction of Democratic Rule in Nigeria 1979-date. In G. Onu, \& A. Momoh (Eds.), Elections and the Future of Democratic Consolidation in Nigeria. Lagos: Nigeria Political Science Association (NPSA).

Akam, F. (2014).Between Fayemi and McCain- Heroism in Defeat. Citizens' Advocate July, 13(6).

Akam, J. B. (2010). Sycophantic Culture, A Cog in the Wheel of Nigeria Democracy. A speech delivered at International Media, Update African Magazine held at Abuja on $20^{\text {th }}$ March.

Apospori, E., Svionitis, G., \& Zisouli. (2010). Political Culture and Perception of Political Marketing Tools: A Cross-Generational Comparison. Journal of Political Marketing, 9(1), 111-134. http://dx.doi.org/10.1080/15377850903472562

Beard, A. (2000). The language of Politics. London: Routledge.

Bello, M. L. (2003). Democratic Secession and Electoral Violence in Nigeria: A critical Appraisal. A paper presented at the $22^{\text {nd }}$ Annual National Conference of the Nigerian Political Science Association (NPSA), held at the Kongo Conference Hotel ABU, Zaria $13-15^{\text {th }}$.

Chiang W. H., \& Park, J. J. (1998). Effectiveness of Negative Political Advertising.

Diamond, L. (2002). A Free and Fair? The Administrative and Conduct of the 1983 Nigerian Elections. In A. A. Akinsanya, \& J. G. Idang (Eds.), Nigerian Government and Politics (1979-1983). Calabar: Wusen Publishers.

Ebegbulem, J. C. (2011). Credible Elections and Democratic Consolidation in Nigeria: The Moral Imperative. Journal of Emerging Trends in Educational Research and Policy Studies (JETERAPS), 2(4), 246-250.

Ejue, B. J., \& Ekanem, S. A. (2011). Voter Rights and Credible Election in Nigeria: The Imperative of Rethinking the Content of Citizenship Education. International Journal of Humanities and Social Science, l(19), 286-294.

Igbuzor, O. (2006).Bulleting aCtion Aid International Nigeria, No 2 - January- June.

Leweanya, K. C. (2013). Credible Electoral System, the Recipe for Good Governance in Nigeria: A Study of INEC (1999-2011), A Seminar paper to the Department of Public Administration, Ebonyi State University, Abakaliki.

Maslow, A. H. (1968).Towards a Psychology of being (2nd ed.). Princeton: Van Nostrand Reinhold.

Nkwede, J. O. (2014). Approaches for Poverty Alleviation and Sustainable Development in Nigeria: A Study of Ebonyi State Community Based Poverty Reduction Agency (EB-CPRA), Redfame Publishing; pp. 153-163.

Nwagboso, C. I., \& Out, D. (2012). Nigeria and the Challenges of Leadership in the $21^{\text {st }}$ Century: A Critique. International Journal of Humanities and Social Science, 2(13), 230-237.

Ochana, N. C., Ndem, E. E., Ogbaji, O. A., Ogbaji, O. A.,\& Ogbole, O. F. E. (2014). Poverty, Inequality and the Challenges of Democratic Consolidation in Nigeria's Forth Republic. Journal of Good Governance and Sustainable Developmentin Africa, 2(1), 48-60. 
Odey, J. O. (2003).This Madness called Elections 2003.Enugu, Ojdjab Publishers.

Ogbonnaya, U. M., Omoju, O. E., \&Udefuna, N. P. (2012).The challenges of Democratic Governance in Nigeria's Fourth Republic. Mediterranean Journal of Social Sciences, 3(11), 685-693.

Olaleye, O. A. (2003). Democracy, Succession and Electoral Violence: The Situation in South-Western Nigeria. A paper presented at the $22^{\text {nd }}$ Annual National Conference of the NPSA, held at ABU, Zaria.

Olujide, J. O., Adeyemi, S. L., \& Gbadeyan, R. A. (2011).Nigerian Electorates' Perception of Political Advertising and Election Campaign. Journal Social Science, 27(3), 179-185.

Onu, \& Momoh.(2005).Electoral and Democratic Consolidation in Nigeria. Lagos: Educational Publishers \& Printers.

Opeibi, B. O. (2004).A Discourse Analysis of the Use of English in the 1993 Presidential Election Campaigns in Nigeria. Ph.D Thesis, Unpublished. University of Lagos, Nigeria.

Osagie, E. (2007). The New Nigerian Economy from Poverty to Prosperity, Benin-City, AFBSN Publishers.

Ovwasa, L. O. (2013). Money Politics and Vote Buying in Nigeria: The Bane of Good Governance. Afro Asia Journal of Social Sciences, 4(4/3), Quarter III, 1-19.

Seteotu, D. (2005). Historical Trajectories of Elections in Nigeria; The State, Political Elites and Electoral Politics. In G. Onu, \& A. Momoh (Eds.), Elections and Democratic Consolidation in Nigeria. Lagos: Educational Publishers \& Printers.

Severin, F. T. (1974). What humanistic psychology is about. Newsletter Feature Supplement. San Francisco: Association for Humanistic Psychology.

Sha, D. P. (2003). When will Democracy End? Interrogating the Relationship between the 2003 Elections and Democratization in Nigeria. A paper presented at the Association of Nigerian (FAAN), held at the National Institute of Policy and Strategic Studies (NIPSS), Kuru-Jos, 30 $30^{\text {th }}$ November $-3^{\text {rd }}$ December, 2003.

Shaffer, J. B. P. (1978). Humanistic Psychology. Englewood Cliffs, N. J.: Prentice Hall.

Udu, L. E. (2013a). Part-time Degree Programmes in Developing Countries: Critical Issues and Implications on Standard: Unpublished Seminar.

Udu, L. E. (2013b). Towards a Free and Fair Elections in Nigeria; a Seminar Paper, August.

Ujo, A. A. (2003). Electoral violence in Nigeria: Problems and prospect a paper presented at the $22^{\text {nd }}$ Annual National Conference of NPSA.

UNDP. (1997). Nigerian Human Development Report. New York: UNDP.

\section{Copyrights}

Copyright for this articleis retained by the author(s), with first publication rights granted to the journal.

This is an open-access article distributed under the terms and conditions of the CreativeCommons Attribution license (http://creativecommons.org/licenses/by/3.0/). 